\title{
АНАЛИЗ ЛЕСНЫХ КВАРТАЛОВ ПО ЧАСТОТЕ ПОЖАРОВ
}

\author{
П.М. Мазуркин
}

Поволжский государственный технологический университет, kaf_po@mail.ru

Приведен способ физико-математического анализа лесных кварталов по частоте пожаров, причем за очаг возгорания принимают лесной квартал, на котором за многолетний период произошло множество лесных пожаров. Это множество принимают с нулевым значением для тех лесных кварталов, на которых не было ни одного пожара. Показана методика расчета частоты лесных пожаров на лесном квартале, координаты его постоянны и зафиксированы в пространстве леса и территории предприятия, причем лесной квартал имеет прямоугольные координаты на карте. Каждый лесной квартал за многолетний период принимают за изменяющийся по количеству лесных пожаров физический объект. Даны распределения по численности прошлых лесных пожаров на данном лесном квартале, а также закономерности изменения частоты пожаров.

Ключевые слова: лесной квартал, пожары, частота, распределения, закономерности

\section{THE ANALYSIS OF FOREST QUARTERS ON THE FREQUENCY OF FIRES}

\section{P.M. Mazurkin}

Volga State Technological University, kaf_po@mail.ru

The way of the physical and mathematical analysis of forest quarters on the frequency of fires is given, and for the center of ignition take forest quarter on which for the long-term period there was a set of forest fires. This set accept with zero value for those forest quarters on which there was no fire. The method of calculation of frequency of forest fires on forest quarter is shown, coordinates it are constant and recorded in space of the wood and the enterprise territory, and forest quarter has rectangular coordinates on the card. Each forest quarter for the long-term period take for changing by number of forest fires physical object. Distributions on the number of last forest fires on this forest quarter, and also regularity of change of frequency of fires are given.

Keywords: forest quarter, fires, frequency, distributions, regularities.

Введение. Предлагаемый способ относится к лесному хозяйству и может быть использован при физико-математическом анализе по статистическим данным о многолетней динамике численности лесных пожаров [1-10] на территории одного или нескольких лесных кварталов, подверженных лесным пожарам. Он может быть использован, прежде всего, в условиях лесничеств и функциональных зон национальных парков, заповедников и других видов особо охраняемых территорий. При наличии добротных многолетних статистических данных способ может быть использован также и в условиях лесничествах эксплуатационного лесного фонда субъекта федерации.

Аналог. Известен способ (ГОСТ Р 22.1.09-99. Безопасность в чрезвычайных ситуациях. Мониторинг и прогнозирование лесных пожаров. Общие требования) мониторинга, включающий контроль на локальном уровне (места лесных пожаров и площади, 
пройденные лесными пожарами) за лесопожарной ситуацией и учету последствий лесных пожаров.

Недостатком является отсутствие контроля лесных кварталов, на которых часто происходят пожары, и тем самым отсутствие обратной связи для территориального планирования природоохранных мероприятий по оперативному тушению вновь возникающих на данном лесном квартале лесных пожаров.

Прототип. Известен также способ физического анализа данных по статистической совокупности данных о текущих лесных пожарах на данной территории (Лесной дозор. URL: http://www.lesdozor.ru/ru/sistemalesnoidozor/opisaniecomplecsa). Физический анализ лесных пожаров включает (в рамках объема притязаний предлагаемого способа выделены укрупненные действия-процедуры) следующие отличительные признаки: 1) определение координат очага возгорания (максимальная ошибка определения координат очага возгорания - 250 м); 2) измерение радиуса обзора одной точки мониторинга до 30 км; 3) точность определения геодезического направления на очаг возгорания не менее $0,5^{\circ}$.

Главным недостатком является отсутствие учета по координатам (радиусу и его геодезического направления) очагов возгорания на одном и том же лесном квартале за продолжительный период наблюдений. Этот недостаток исходит из того факта, что за объекты анализа приняты сами лесные пожары, а не лесные земельные участки, подверженные этим лесным пожарам. В итоге частота лесных пожаров, возникших за продолжительное время на одном и том же лесном квартале, вообще не рассматривается.

В итоге не удается дополнительно к физическому анализу проводить математический анализ каждого лесного квартала по многолетнему распределению численности лесных пожаров. Отсутствие физико-математического анализа численности пожаров не дает возможности прогнозировать вероятность появления лесных пожаров по тем лесным кварталам, на которых произошло наибольшее количество лесных пожаров. Это не позволяет управлять режимом контроля и мощностью пожарных служб лесничеств.

Технический результат - повышение функциональных возможностей физикоматематического анализа лесных кварталов по многолетней численности лесных пожаров, а также точности инерционного прогнозирования лесных пожаров, на лесном квартале, выявлением устойчивых трендов и волновых закономерностей распределений численности лесных пожаров по наиболее подверженным пожарам лесным кварталам.

Сущность способа. Каждый лесной квартал за многолетний период принимают за изменяющийся по количеству лесных пожаров объект, а затем все лесные квартала лес- 
ного предприятия (или его структурных подразделений в виде лесничеств, а на особо охраняемых территориях дополнительно также по функциональным зонам) распределяют по численности прошлых лесных пожаров, происшедших на данном лесном квартале. При этом для прогнозирования принимают допущение, что вероятность появления лесных пожаров в будущем на данном лесном квартале пропорциональна количеству бывших на его территории пожаров.

Для тех лесных кварталов, на которых за рассматриваемый период в прошлом не было ни одного лесного пожара, принимают нулевую численность прошлых лесных пожаров, происшедших на данном лесном квартале. Время контроля системы «Дозор» распределяют по всем лесным кварталам лесного предприятия пропорционально численности прошлых лесных пожаров, происшедших на данном лесном квартале.

Реализация метода. Способ анализа лесных кварталов по частоте пожаров, например, для особо охраняемой территории в виде национального парка, выполняется следующим образом.

Вначале выясняют по журналу учета лесных пожаров промежуток времени, за который структура функциональных зон и лесничеств не менялась.

Начало периода распределения принимают с момента изменения структуры территориального управления национальным парком, а за конец периода принимают последний текущий год до момента распределения. После этого из журнала учета лесных пожаров выписывают по всем многолетним данным количества лесных пожаров, происшедших на каждом лесном квартале лесничества или же функциональной зоне.

За очаг возгорания принимают лесной квартал, на котором за многолетний период произошло множество лесных пожаров. Причем это множество принимают с нулевым значением для тех лесных кварталов, ан которых не было ни одного лесного пожара. А время контроля координат каждого лесного квартала рассчитывают исходя из частоты лесных пожаров, происшедших на рассматриваемом лесном квартале, причем для тех лесных кварталов, на которых за многолетний период не произошло ни одного лесного пожара, выделяют минимальное время для противопожарного контроля.

Координаты будущего лесного пожара неизвестны и случайны, а координаты лесного квартала постоянны и четко зафиксированы двумя способами: во-первых, в пространстве леса и территории предприятия и лесной квартал имеет четкие прямоугольные координаты на карте; во-вторых, в системе «Дозор» лесной квартал получает полярные координаты в виде радиуса и угла геодезического направления. 
Каждый лесной квартал за многолетний период принимают за изменяющийся по количеству лесных пожаров физический объект. Затем все лесные квартала лесного предприятия, также его структурных подразделений в виде лесничеств, а на особо охраняемых территориях дополнительно также по функциональным зонам, распределяют по численности прошлых лесных пожаров, происшедших на данном лесном квартале. При этом для прогнозирования принимают допущение, что вероятность появления лесных пожаров в будущем на данном лесном квартале пропорциональна количеству бывших на его территории пожаров.

Для тех лесных кварталов, на которых за рассматриваемый период в прошлом не было ни одного лесного пожара, принимают нулевую численность прошлых лесных пожаров, происшедших на данном лесном квартале, причем время контроля системы «Дозор» распределяют по всем лесным кварталам лесного предприятия пропорционально численности прошлых лесных пожаров, происшедших на данном лесном квартале.

Дополнительно к физическому анализу проводить математический анализ каждого лесного квартала по многолетнему распределению численности лесных пожаров, а точность инерционного прогнозирования лесных пожаров в будущем повышают выявлением устойчивых трендов и волновых закономерностей распределений численности лесных пожаров по наиболее подверженным пожарам лесным кварталам по формуле:

$$
\begin{array}{r}
N=a_{1} \exp \left(-a_{2} n_{\kappa \varepsilon}{ }^{a_{3}}\right)+A \cos \left(\pi n_{\kappa \varepsilon} / p+a_{11}\right), \\
A=a_{4} n_{\kappa \beta}{ }^{a_{5}} \exp \left(-a_{6} n_{\kappa \beta}{ }^{a_{7}}\right), p=a_{8}+a_{9} n_{\kappa \beta}{ }^{a_{10}},
\end{array}
$$

где $\quad N$ - численность лесных кварталов с лесными пожарами, шт.,

$n_{\kappa в}$ - количество лесных пожаров, происшедших на одном и том же лесном квартале, причем $0 \leq n_{\kappa в} \leq n_{\max }$, шт.,

$n_{\max }$ - максимальное количество лесных пожаров за определенный период измерений, например за 25 лет, на одном лесном квартале, шт.,

$A$ - амплитуда (половина) колебания лесных кварталов как отклик на многолетнее воздействие лесных пожаров, шт.,

$p$ - полупериод колебательного возмущения лесных кварталов на шкале $0 \leq n_{\kappa в} \leq n_{\max }$ количества пожаров на одном лесном квартале, шт., $a_{1} \ldots a_{11}$ - параметры формулы, принимающие конкретные числовые значения при идентификации формулы по статистическим данным о численности лесных пожаров. 
Объект исследования. Государственный природный Национальный парк «Марий Чодра» организован 1 декабря 1985 года. Марий Чодра, в переводе, означает «марийский лес». И назван он так не случайно - вся территория парка покрыта прекрасными сосновыми борами и хвойно-широколиственными лесами. Парк находится на юго-востоке республики, в трех административных районах - Моркинском, Звениговском, Волжском - в 20-40 км от г. Волжска и 50-70 км от столицы Республики Марий Эл г. Йошкар-Олы.

Регистрация лесных пожаров. В таблице 1 приведено распределение каждого лесного квартала с количеством лесных пожаров по лесничествам (столбцы) и функциональным зонам (строки), причем последние имеют следующие условные обозначения: Ф31 - зона заповедного режима 7590 га; Ф32 - зона особо охраняемая 4772 га; Ф33 - зона экстенсивного рекреационного использования 11248 га; Ф34 - зона интенсивного рекреационного использования 12039 га; Ф35 - зона хозяйственного назначения 1226 га.

Таблица 1. Квартала с лесными пожарами по лесничествам и функциональным зонам за 1987-2011 гг.

\begin{tabular}{|c|c|c|c|c|c|c|c|}
\hline \multicolumn{2}{|c|}{ Керебелякское } & \multicolumn{2}{|c|}{ Кленовогорское } & \multicolumn{2}{|c|}{ Лушмарское } & \multicolumn{2}{|c|}{ Яльчинское } \\
\hline № кв. & $n_{\kappa B}$, шт. & № кв. & $n_{\kappa \theta}$, шт. & № кв. & $n_{\kappa \varepsilon}$, шт. & № кв. & $n_{\kappa \beta}$, шт. \\
\hline \multicolumn{8}{|c|}{ Ф31- зона заповедного режима } \\
\hline 47 & 1 & 76 & 1 & & & & \\
\hline 60 & 1 & & & & & & \\
\hline 62 & 1 & & & & & & \\
\hline 66 & 1 & & & & & & \\
\hline 67 & 1 & & & & & & \\
\hline 71 & 1 & & & & & & \\
\hline \multicolumn{8}{|c|}{ Ф32 - зона особо охраняемая } \\
\hline & & & & 27 & 1 & 1 & 1 \\
\hline & & & & 29 & 2 & 7 & 2 \\
\hline & & & & 66 & 2 & & \\
\hline & & & & 71 & 1 & & \\
\hline & & & & 73 & 1 & & \\
\hline \multicolumn{8}{|c|}{ Ф33 - зона экстенсивного рекреационного использования } \\
\hline 53 & 1 & 31 & 1 & 73 & 1 & 12 & 2 \\
\hline \multirow[t]{12}{*}{55} & 1 & 45 & 3 & 1 & 1 & 13 & 2 \\
\hline & & 46 & 1 & 37 & 2 & 24 & 2 \\
\hline & & 51 & 2 & 43 & 2 & 25 & 2 \\
\hline & & 52 & 3 & 47 & 1 & 27 & 9 \\
\hline & & 58 & 5 & 53 & 1 & 33 & 3 \\
\hline & & 59 & 1 & 55 & 2 & 34 & 2 \\
\hline & & 60 & 1 & 56 & 4 & 35 & 2 \\
\hline & & 61 & 1 & 69 & 2 & 70 & 5 \\
\hline & & 63 & 1 & 74 & 2 & & \\
\hline & & 64 & 1 & 76 & 2 & & \\
\hline & & 66 & 1 & 87 & 1 & & \\
\hline & & 72 & 2 & & & & \\
\hline \multicolumn{8}{|c|}{ Ф34 - зона интенсивного рекреационного использования } \\
\hline & & 6 & 1 & 17 & 1 & 28 & 1 \\
\hline
\end{tabular}




\begin{tabular}{|c|c|c|c|c|c|c|c|}
\hline \multicolumn{2}{|c|}{ Керебелякское } & \multicolumn{2}{|c|}{ Кленовогорское } & \multicolumn{2}{|c|}{ Лушмарское } & \multicolumn{2}{|c|}{ Яльчинское } \\
\hline № кв. & $n_{\kappa \beta}$, шт. & № кв. & $n_{\kappa в}$, шт. & № кв. & $n_{\kappa \varepsilon}$, шт. & № кв. & $n_{\kappa 6}$, шт. \\
\hline & & 16 & 2 & 26 & 1 & 36 & 3 \\
\hline & & 23 & 2 & 30 & 10 & 37 & 4 \\
\hline & & 24 & 1 & 31 & 1 & 5 & 5 \\
\hline & & 25 & 3 & 32 & 2 & 8 & 3 \\
\hline & & 26 & 2 & 34 & 1 & 10 & 1 \\
\hline & & 27 & 1 & 38 & 3 & 17 & 1 \\
\hline & & 30 & 1 & 39 & 3 & 19 & 1 \\
\hline & & 33 & 1 & 45 & 1 & 20 & 1 \\
\hline & & 39 & 2 & 46 & 1 & 30 & 2 \\
\hline & & 40 & 1 & 50 & 2 & 31 & 4 \\
\hline & & 41 & 1 & 54 & 3 & 38 & 3 \\
\hline & & 44 & 2 & 57 & 1 & 39 & 1 \\
\hline & & 49 & 1 & 60 & 1 & 40 & 1 \\
\hline & & 70 & 8 & 61 & 3 & 41 & 3 \\
\hline & & & & 62 & 1 & 43 & 5 \\
\hline & & & & & & 44 & 8 \\
\hline & & & & & & 45 & 10 \\
\hline & & & & & & 46 & 3 \\
\hline & & & & & & 47 & 1 \\
\hline & & & & & & 48 & 1 \\
\hline & & & & & & 49 & 1 \\
\hline & & & & & & 52 & 7 \\
\hline & & & & & & 53 & 3 \\
\hline & & & & & & 58 & 2 \\
\hline & & & & & & ч61 & 1 \\
\hline & & & & & & 62 & 2 \\
\hline & & & & & & 63 & 4 \\
\hline & & & & & & 64 & 4 \\
\hline & & & & & & 67 & 3 \\
\hline & & & & & & 68 & 6 \\
\hline & & & & & & 69 & 1 \\
\hline \multicolumn{8}{|c|}{ Ф35 - зона хозяйственного назначения } \\
\hline & & 22 & 6 & 458 & 2 & ч60 & 3 \\
\hline & & 50 & 4 & 59 & 2 & ч66 & 4 \\
\hline & & 57 & 1 & ч64 & 1 & 23 & 2 \\
\hline & & & & & & 32 & 1 \\
\hline & & & & & & 42 & 1 \\
\hline & & & & & & 51 & 3 \\
\hline & & & & & & 59 & 5 \\
\hline & & & & & & 65 & 3 \\
\hline
\end{tabular}

Книга учета лесных пожаров ФГБУ «Национальный парк «Марий Чодра» представляет собой журнал, в котором записывают все известные ему данные о возгорании.

Далее рассмотрим распределения численности лесных пожаров за 25 лет с 1987 по 2011 гг. (рис. 1). До 1987 года распределение лесничеств и их лесных кварталов было иным. Поэтому период 1982-1986 гг. не рассматривался. 
Регистрация лесных кварталов. В таблице 2 приведено распределение лесных кварталов по лесничествам (столбцы) и функциональным зонам (строки).

Таблица 2. Всего лесных кварталов в национальном парке «Марий Чодра»

\begin{tabular}{|c|c|c|c|c|c|}
\hline \multirow{2}{*}{$\begin{array}{c}\text { Функциональные } \\
\text { зоны }\end{array}$} & \multicolumn{4}{|c|}{ Лесничество } & \multirow{2}{*}{ Итого } \\
\hline & Керебелякское & Кленовогорское & Лушмарское & Яльчинское & \\
\hline Ф31 & 57 & 12 & 0 & 0 & 69 \\
\hline Ф32 & 3 & 20 & 12 & 4 & 39 \\
\hline Ф33 & 22 & 29 & 43 & 13 & 107 \\
\hline Ф34 & 1 & 32 & 33 & 44 & 110 \\
\hline Ф35 & 1 & 5 & 4 & 12 & 22 \\
\hline Итого & 84 & 98 & 92 & 73 & 347 \\
\hline
\end{tabular}

Количество лесных кварталов без пожаров за 25 лет дано в таблице 3.

Таблица 3. Всего лесных кварталов без пожаров за 1987-2011 гг.

\begin{tabular}{|c|c|c|c|c|c|}
\hline \multirow{2}{*}{$\begin{array}{c}\text { Функциональные } \\
\text { зоны }\end{array}$} & \multicolumn{4}{|c|}{ Лесничество } & \multirow{2}{*}{ Итого } \\
\cline { 2 - 5 } Ф31 & Керебелякское & Кленовогорское & Лушмарское & Яльчинское & \\
\hline$\Phi 32$ & 51 & 11 & 0 & 0 & 62 \\
\hline$\Phi 33$ & 20 & 20 & 7 & 2 & 32 \\
\hline$\Phi 34$ & 1 & 16 & 32 & 4 & 72 \\
\hline Ф35 & 1 & 17 & 17 & 12 & 47 \\
\hline Итого & 76 & 66 & 57 & 0 & 4 \\
\hline
\end{tabular}

Лесные кварталы, на которых хотя бы один раз произошел лесной пожара, представлены в таблице 4.

Таблица 4. Всего лесных кварталов, пройденных пожарами

\begin{tabular}{|c|c|c|c|c|c|}
\hline \multirow{2}{*}{$\begin{array}{c}\text { Функциональные } \\
\text { зоны }\end{array}$} & \multicolumn{4}{|c|}{ Лесничество } & \multirow{2}{*}{ Итого } \\
\hline & Керебелякское & Кленовогорское & Лушмарское & Яльчинское & \\
\hline Ф31 & 6 & 1 & 0 & 0 & 7 \\
\hline Ф32 & 0 & 0 & 5 & 2 & 7 \\
\hline$\Phi 33$ & 2 & 13 & 11 & 9 & 35 \\
\hline Ф34 & 0 & 15 & 16 & 32 & 63 \\
\hline Ф35 & 0 & 3 & 3 & 12 & 18 \\
\hline Итого & 8 & 32 & 35 & 55 & 130 \\
\hline
\end{tabular}

Для сравнения национального парка с другими лесными предприятиями в таблице

5 даны относительная доля лесных кварталов, в которых произошли лесные пожары.

Таблица 5. Доля лесных кварталов, в которых хотя бы один раз был пожар

\begin{tabular}{|c|c|c|c|c|c|}
\hline \multirow{2}{*}{$\begin{array}{c}\text { Функциональные } \\
\text { зоны } \\
\end{array}$} & \multicolumn{4}{|c|}{ Лесничество } & \multirow{2}{*}{ Итого } \\
\hline & Керебелякское & Кленовогорское & Лушмарское & Яльчинское & \\
\hline Ф31 & 10.53 & 8.33 & 0 & 0 & 10.14 \\
\hline Ф32 & 0.00 & 0.00 & 41.67 & 50.00 & 17.95 \\
\hline Ф33 & 9.09 & 44.83 & 25.58 & 69.23 & 32.71 \\
\hline Ф34 & 0.00 & 46.88 & 48.48 & 72.73 & 57.27 \\
\hline Ф35 & 0.00 & 60.00 & 75.00 & 100.00 & 81.82 \\
\hline Итого & 9.52 & 32.65 & 38.04 & 75.34 & 37.46 \\
\hline
\end{tabular}

На территории наблюдается разброс относительного показателя от 0 до $100 \%$. 
Количество лесных пожаров за 25 лет регистрации изменяется по таблице 6.

Таблица 6. Количество лесных пожаров за период 1987-2011 гг.

\begin{tabular}{|c|c|c|c|c|c|}
\hline \multirow{2}{*}{$\begin{array}{c}\text { Функциональные } \\
\text { зоны }\end{array}$} & \multicolumn{4}{|c|}{ Лесничество } & \multirow{2}{*}{ Итого } \\
\hline & Керебелякское & Кленовогорское & Лушмарское & Яльчинское & \\
\hline Ф31 & 6 & 1 & 0 & 0 & 7 \\
\hline Ф32 & 0 & 0 & 7 & 3 & 10 \\
\hline Ф33 & 2 & 23 & 20 & 29 & 74 \\
\hline Ф34 & 0 & 29 & 35 & 96 & 160 \\
\hline Ф35 & 0 & 11 & 5 & 26 & 42 \\
\hline Итого & 8 & 64 & 67 & 154 & 293 \\
\hline
\end{tabular}

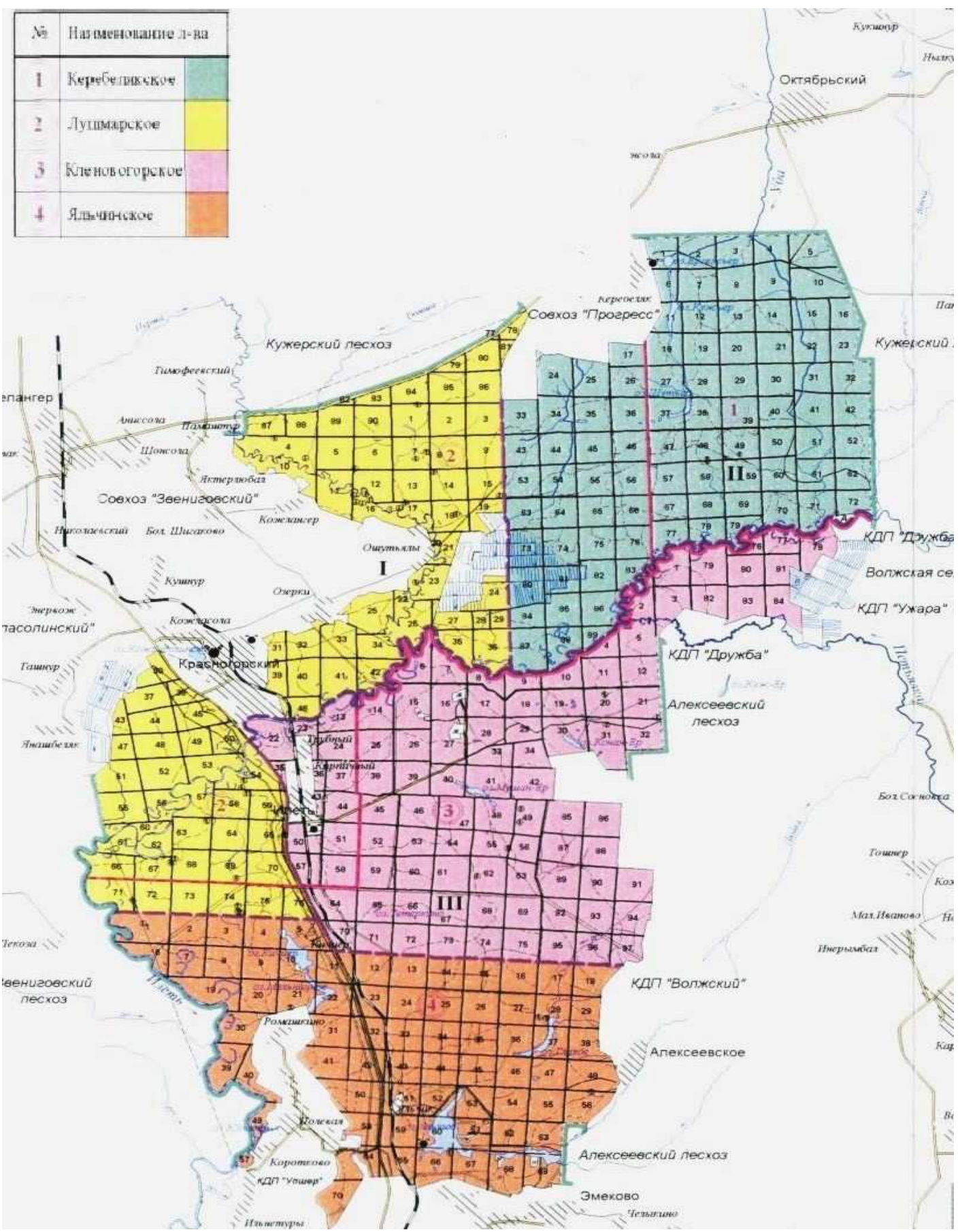

Рис. 1. Карта-схема территории национального парка «Марий Чодра» 
Сравнение данных таблиц 4 и 6 показывает, что 293 лесных пожара произошли на 130 лесных кварталах (рис. 2). Однако среднее арифметическое значение числа пожаров не подходит, так как на некоторых лесных кварталах за 25 лет произошло много пожаров. Поэтому за объект исследования нужно брать не сам лесной пожар, а лесной квартал, на котором произошел это пожар.

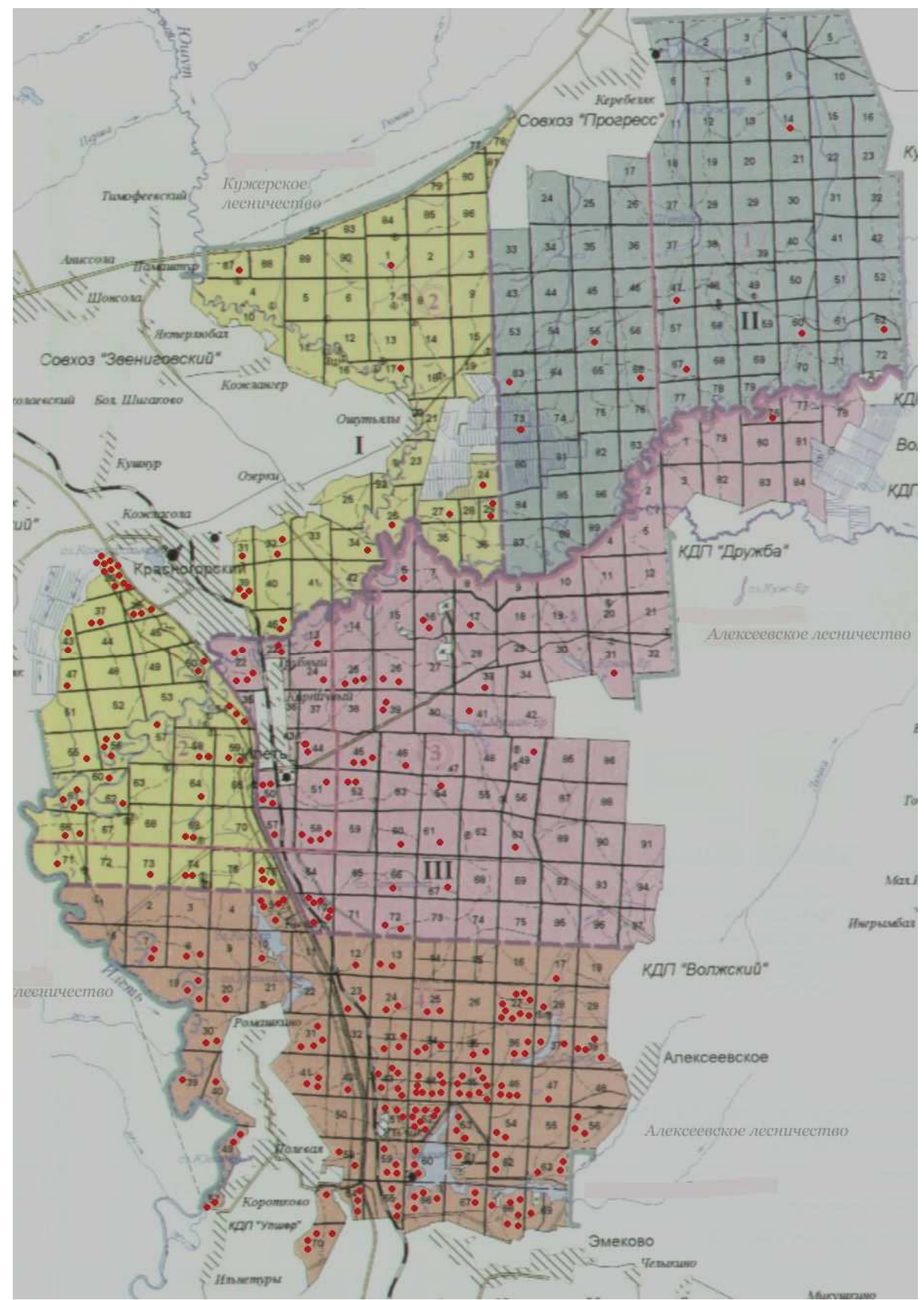

Рис. 2. Карта-схема территории национального парка «Марий Чодра» с отметкой на лесных кварталах каждого лесного пожара в виде точки 
В итоге один материальный объект (лесной пожар) заменяется на природный материальный объект - лесной земельный участок принятых размеров и формы - лесной квартал. Он четко зафиксирован в лесу и на территории лесного предприятия и имеет точные координаты, радиус и угол геодезического направления для системы «Дозор».

Время контроля автоматизированной системой рассчитывается исходя из частоты лесных пожаров, происшедших на рассматриваемом лесном квартале. А те лесные квартала, на которых за 25 лет не произошло ни одного лесного пожара, можно выделять для противопожарного контроля гораздо меньшее время.

Распределение по лесничествам. В таблице 7 приведено количество пожаров с учетом распределения их количества за 25 лет по лесничествам.

Таблица 7. Количество пожаров на лесных кварталах на территории ФГУ «Национальный парк «Марий Чодра» за 1987-2011 гг. по лесничествам

\begin{tabular}{|c|c|c|c|c|c|}
\hline \multirow{2}{*}{$\begin{array}{c}\text { Количество пожаров } \\
\text { на лесном квартале } \\
n_{\kappa \varepsilon}, \text { шт. }\end{array}$} & \multicolumn{4}{|c|}{ Количество $N_{Л}$ лесных кварталов по лесничествам } & \multirow{2}{*}{$\begin{array}{l}\text { Всего кварталов } \\
\text { по НП «Марий } \\
\text { Чодра» } N_{n}, \text { шт. }\end{array}$} \\
\hline & $\begin{array}{l}\text { Керебеляк- } \\
\text { ское }\end{array}$ & $\begin{array}{c}\text { Кленовогор- } \\
\text { ское }\end{array}$ & $\begin{array}{l}\text { Лушмар- } \\
\text { ское }\end{array}$ & Яльчинское & \\
\hline 0 & 76 & 66 & 57 & 18 & 217 \\
\hline 1 & 8 & 18 & 17 & 15 & $\begin{array}{l}58 \\
\end{array}$ \\
\hline 2 & 0 & 7 & 12 & 13 & 32 \\
\hline 3 & 0 & 3 & 4 & 11 & 18 \\
\hline 4 & 0 & 1 & 1 & 5 & 7 \\
\hline 5 & 0 & 1 & 0 & 4 & 5 \\
\hline 6 & 0 & 1 & 0 & 1 & 2 \\
\hline 7 & 0 & 0 & 0 & 1 & 1 \\
\hline 8 & 0 & 1 & 0 & 1 & 2 \\
\hline 9 & 0 & 0 & 0 & 1 & 1 \\
\hline 10 & 0 & 0 & 1 & 1 & 2 \\
\hline Итого кварталов & 84 & 98 & 92 & 71 & $345^{*}$ \\
\hline Итого пожаров & 8 & 64 & 67 & 154 & 293 \\
\hline
\end{tabular}

Примечание: *Два квартала не имели достоверных данных о пожарах.

Общее количество пожаров $\sum N=293$ шт. определяется по формуле

$$
\sum N_{n}=\sum_{n_{\kappa \beta}=0}^{10} N_{n} n_{\kappa \beta} .
$$

Аналогично для лесничеств получаем уравнение количества пожаров

$$
\sum N_{Л}=\sum_{n_{\kappa 8}=0}^{10} N_{J} n_{\kappa в} .
$$

Таким образом, все имеющиеся лесные кварталы условно имеют значения частоты лесных пожаров. Но при этом на тех лесных кварталах, на которых за 25 лет не произошли ни одного лесного пожара, принимается значение количества лесных пожаров на одном и том же лесном квартале $n_{\kappa в}=0$. 
Из данных таблицы 7 видно, что наибольшее количество пожаров равно 10 и при этом столько пожаров произошло на двух лесных кварталах по всему национальному парку (по одному лесному кварталу Лушмарского и Яльчинского лесничеств). Далее за влияющую переменную примем $n_{\kappa \varepsilon}$.

Общее количество кварталов $N_{n}$, в зависимости от количества пожаров на одном лесном квартале, изменяется по формуле (рис. 3) закона экспоненциальной гибели

$$
N_{n}=216.9377 \exp \left(-1.29352 n_{\kappa в}{ }^{0.63570}\right) .
$$

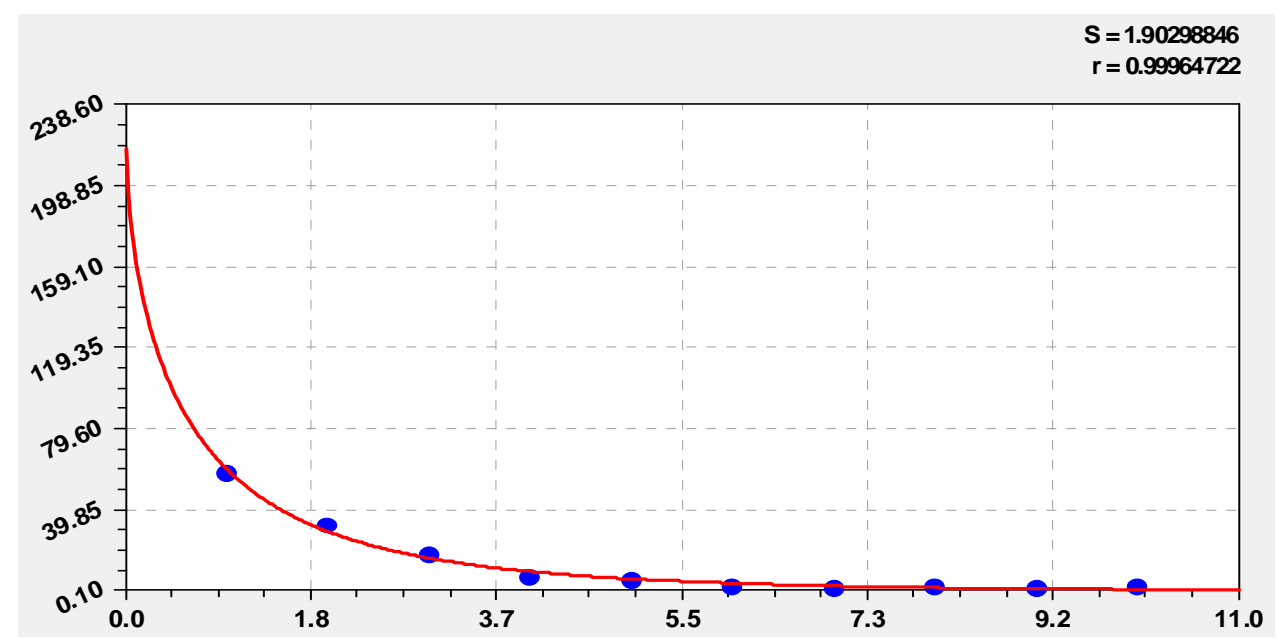

Рис. 3. График распределения количества кварталов в зависимости от изменения количества лесных пожаров на одном лесном квартале

Первый параметр при $n_{\kappa в}=0$ показывает количество лесных кварталов, на которых не было ни одного лесного пожара.

Керебелякское лесничество (рис. 4) получает закономерность вида

$$
N_{Л}=76.00875 \exp \left(-2.27275 n_{\kappa в}\right) .
$$

Кленовогорское лесничество (рис. 4) дает формулу

$$
N_{Л}=66.00405 \exp \left(-12.30229 n_{\kappa в}^{0.78010}\right) \text {. }
$$

Лушмарское лесничество (рис. 4) имеет сложную структуру распределения лесных кварталов по количеству пожаров на одном лесном квартале по биотехнической закономерности с волновой составляющей

$$
N_{Л}=57.00001 \exp \left(-1.49684 n_{\kappa в}^{1.07955}\right)+A \cos \left(\pi n_{\kappa в} / p+1.33941\right),
$$

$A=3.75424 \cdot 10^{10} n_{\kappa в}{ }^{14.62931} \exp \left(-19.82605 n_{\kappa в}{ }^{0.51817}\right), p=5.98044+10.97285 n_{\kappa в}{ }^{1.12734}$, где $A$ - амплитуда (половина) колебательного возмущения популяции лесных кварталов как отклик на многолетнее воздействие лесных пожаров, шт.; $p$ - полупериод колеба- 
тельного возмущения лесных кварталов на шкале количества лесных пожаров на одном лесном квартале, шт.

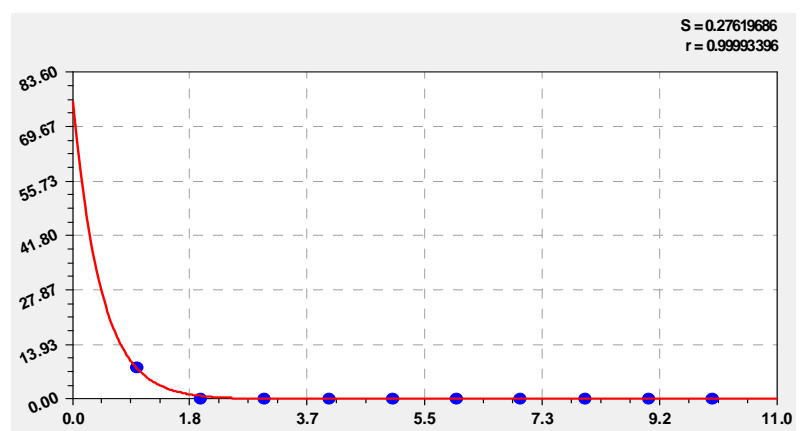

Распределение лесных кварталов с пожарами по Керебелякскому лесничеству

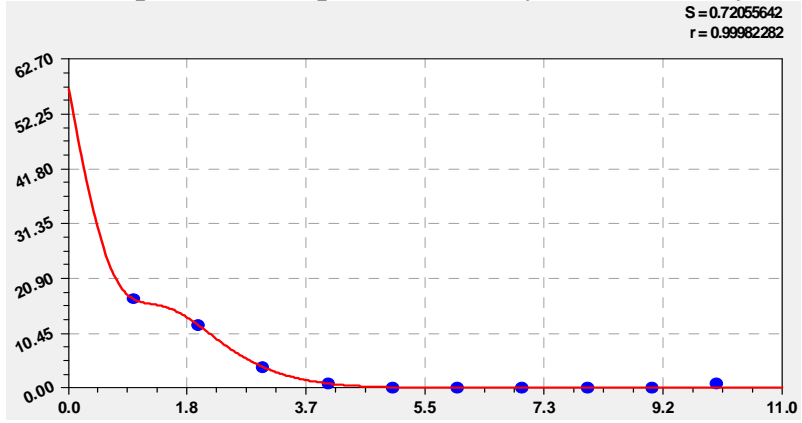

Распределение лесных кварталов с пожарами по Лушмарскому лесничеству

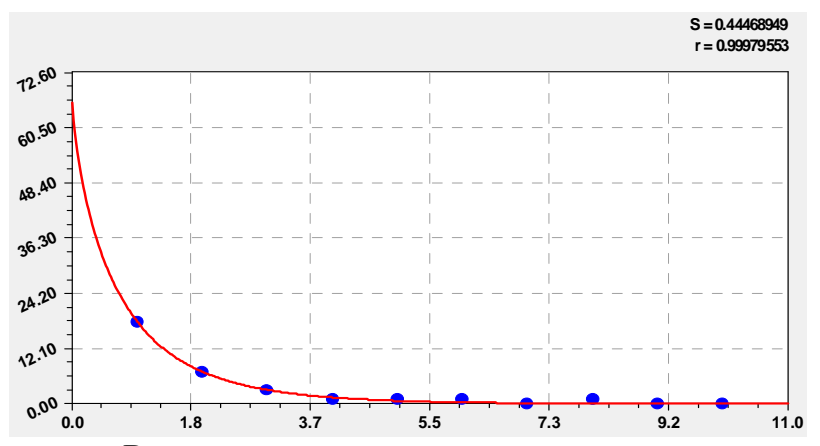

Распределение лесных кварталов с пожарами по Кленовогорскому лесничеству

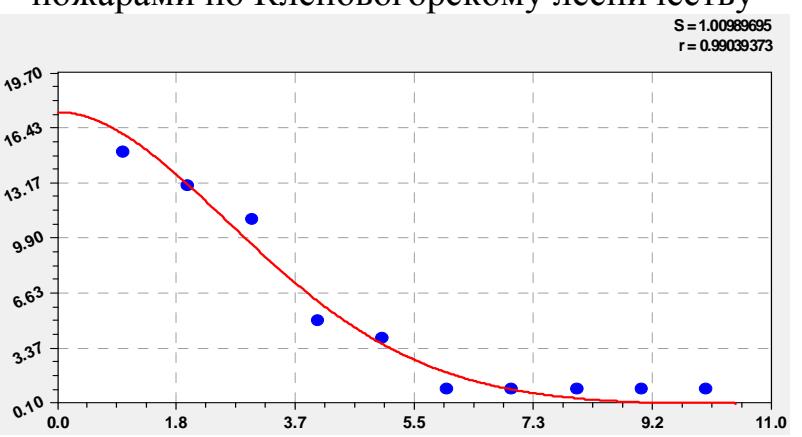

Распределение лесных кварталов с пожарами по Яльчинскому лесничеству

Рис. 4. График распределения количества кварталов в зависимости от изменения количества лесных пожаров на одном лесном квартале для четырех лесничеств национального парка «Марий Чодра»

Яльчинское лесничество(рис. 4) получает также закон гибели

$$
N_{J}=17.37682 \exp \left(-0.078199 n_{\kappa в}^{1.86356}\right) .
$$

Остатки после всех приведенных формул показывают наличие дополнительной волны возмущения, однако их точность мала по сравнению с погрешностью измерений численности лесных пожаров. Закономерности по отдельным лесничествам и в целом по их объединению можно получать для любых лесных предприятий, территория которых разделена на сетку лесных кварталов.

Распределение по функциональным зонам. Особо охраняемые территории имеют дополнительно к распределению по лесничествам еще и распределения лесных кварталов по функциональным зонам. Причем сами функциональные зоны четко ранжированы по уровню возрастания антропогенной (рекреация, хозяйственная и иная деятельность) нагрузки.

Распределения лесных кварталов по функциональным зонам даны в таблице 8. 
Таблица 8. Количество пожаров на лесных кварталах на территории ФГУ «Национальный парк «Марий Чодра» за 1987-2011 гг. по функциональным зонам

\begin{tabular}{|c|c|c|c|c|c|c|}
\hline \multirow{2}{*}{$\begin{array}{c}\text { Количество } \\
\text { пожаров } \\
\text { на лесном } \\
\text { квартале } \\
n_{\kappa в}, \text { шт. }\end{array}$} & \multicolumn{5}{|c|}{ Количество $N_{\Phi 3}$ лесных кварталов по функциональным зонам } & \multirow{2}{*}{$\begin{array}{c}\text { Всего } \\
\text { по НП } \\
\text { «Марий } \\
\text { Чодра» } \\
N_{n}, \text { шт. }\end{array}$} \\
\hline & $\begin{array}{c}\text { заповедного } \\
\text { режима }\end{array}$ & $\begin{array}{c}\text { особо } \\
\text { охраняемая }\end{array}$ & \begin{tabular}{|c|} 
экстенсивного \\
рекреацион- \\
ного исполь- \\
зования
\end{tabular} & $\begin{array}{c}\text { интенсивного } \\
\text { рекреацион- } \\
\text { ного исполь- } \\
\text { зования }\end{array}$ & $\begin{array}{c}\text { Хозяйств- } \\
\text { енного } \\
\text { назначения }\end{array}$ & \\
\hline 0 & 62 & 32 & 72 & 47 & 4 & 217 \\
\hline 1 & 7 & 4 & 14 & 29 & 4 & 58 \\
\hline 2 & 0 & 3 & 14 & 10 & 5 & 32 \\
\hline 3 & 0 & 0 & 3 & 12 & 3 & 18 \\
\hline 4 & 0 & 0 & 1 & 4 & 2 & 7 \\
\hline 5 & 0 & 0 & 2 & 2 & 1 & 5 \\
\hline 6 & 0 & 0 & 0 & 1 & 1 & 2 \\
\hline 7 & 0 & 0 & 0 & 1 & 0 & 1 \\
\hline 8 & 0 & 0 & 0 & 2 & 0 & 2 \\
\hline 9 & 0 & 0 & 1 & 0 & 0 & 1 \\
\hline 10 & 0 & 0 & 0 & 2 & 0 & 2 \\
\hline Итого кв. & 69 & 39 & 107 & 110 & 20 & 345 \\
\hline $\begin{array}{c}\text { Итого } \\
\text { пожаров }\end{array}$ & 7 & 10 & 74 & 160 & 42 & 293 \\
\hline
\end{tabular}

Для функциональных зон получаем уравнение количества пожаров

$$
\sum N_{\Phi 3}=\sum_{n_{\kappa 8}=0}^{10} N_{\Phi 3} n_{\kappa в} .
$$

Тогда, снимая индексы, получаем выражение для подсчета общего числа лесных пожаров по лесничествам и функциональным зонам национального парка вида

$$
\Sigma_{N}=\sum_{n_{\kappa \beta}=0}^{n_{\max }} N_{\left(n_{\kappa \beta}\right)} \cdot n_{\kappa \beta},
$$

где $\sum_{N}$ - сумма лесных пожаров по лесничествам, шт., $n_{\kappa в}$ - количество лесных пожаров на лесном квартале, шт., $n_{\max }$ - максимальное количество лесных пожаров за определенный период измерений на одном лесном квартале, шт., $N_{\left(n_{k в}\right)}$ - количество лесных кварталов с данным значением $n_{\kappa в}$ при изменении в интервале $0 \leq n_{\kappa в} \leq n_{\max }$, шт.

Затем рассмотрим закономерности по отдельным функциональным зонам национального парка «Марий Чодра».

На зоне заповедного режима (рис. 5) получена зависимость вида

$$
N_{\Phi 3}=62.00936 \exp \left(-2.20579 n_{\kappa в}\right) \text {. }
$$

На особо охраняемой зоне (рис. 6) выполняется закон экспоненциальной гибели

$$
N_{\Phi 3}=31.95113 \exp \left(-1.92286 n_{\kappa \beta}\right) .
$$




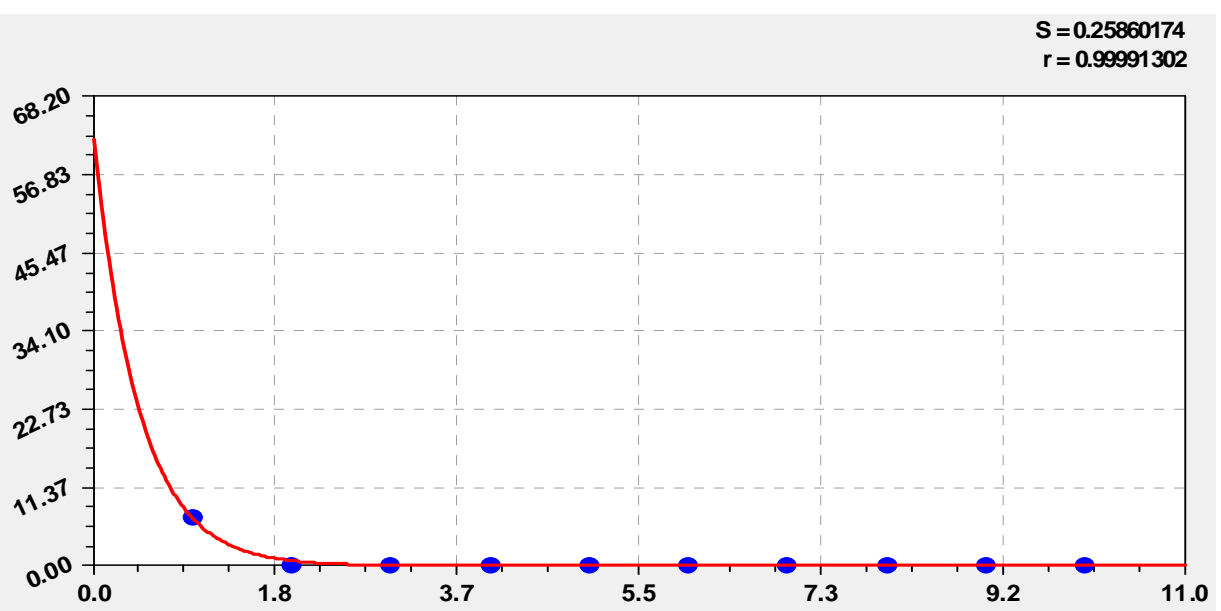

Рис. 5. График распределения лесных кварталов с разным количеством лесных пожаров по зоне заповедного режима

На зоне экстенсивного рекреационного использования (рис. 6):

$$
N_{\Phi 3}=71.94865 \exp \left(-1.49370 n_{\kappa в}^{0.54817}\right) .
$$

На зоне интенсивного рекреационного использования (рис. 6):

$$
N_{\Phi 3}=47.28909 \exp \left(-0.56464 n_{\kappa в}^{1.03489}\right) .
$$

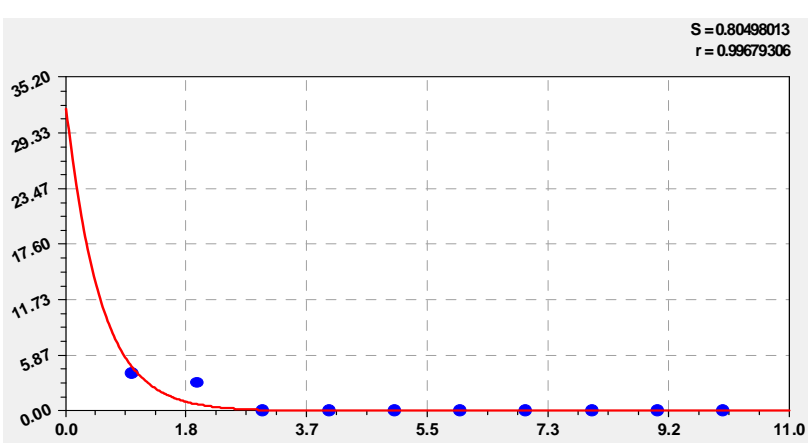

Распределение лесных кварталов с пожарами на особо охраняемой зоне

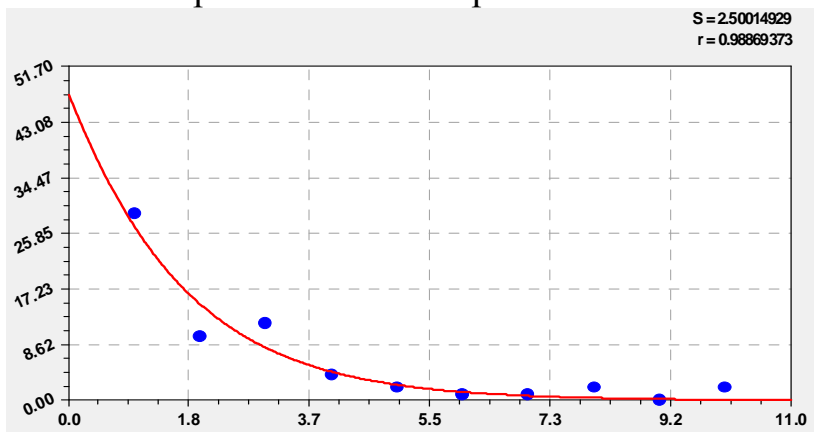

Распределение лесных кварталов с пожарами на зоне интенсивной рекреации

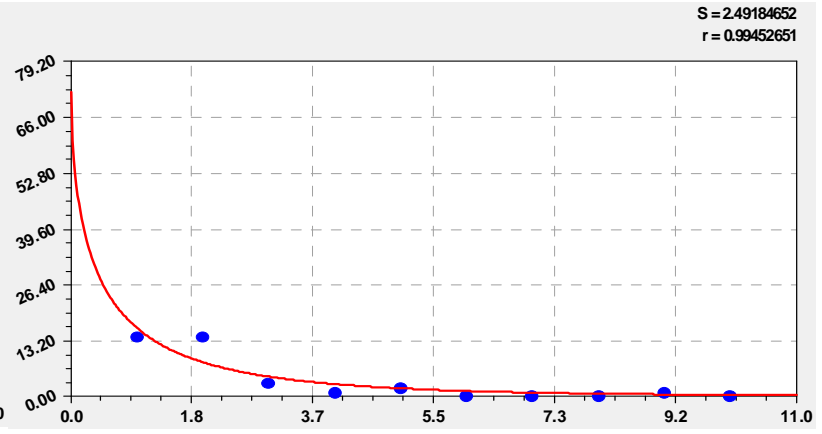

Распределение лесных кварталов с пожарами на зоне экстенсивной рекреации $S=0.45917124$ $r=0.97604763$

Рис. 6. График распределения лесных кварталов с разным количеством лесных пожаров по остальным четырем функциональным зонам национального парка «Марий Чодра»

На зоне хозяйственного назначения (рис. 6) национального парка «Марий Чодра» количество лесных кварталов распределяется по биотехнической закономерности вида 


$$
N_{\Phi 3}=4.33407 \exp \left(-0.010234 n_{\kappa в}^{3.01562}\right) .
$$

Таким образом, общая закономерность у всех распределений - это закон гибели в экспоненциальной форме.

Заключение. Предлагаемый способ обладает простотой реализации, так как по фактическим прошлым многолетним данным о лесных пожарах на конкретной территории необходимо только выписать данные о количестве лесных пожаров на каждом лесном квартале. При этом методом «точкования» заполняется таблица 1 и затем составляются таблицы $2-8$.

Применение предложенного способа расширяет возможности территориального экологического мониторинга, повышает функциональные возможности системы типа «Лесной Дозор» за счет распределения времени наблюдений по параметру $n_{\kappa в}$, то есть по увеличению количества лесных пожаров, происшедших на конкретном лесном квартале. При этом используются координаты каждого лесного квартала.

В итоге появляется практическая возможность, с использованием многолетних данных о лесных пожарах на территории, проведения экологического и технологического (пожаротушения) мониторинга для прогнозирования и уточнения распределения лесных пожаров вдоль радиуса обзора, а также провести прогнозный расчет по каждому лесному кварталу вероятности будущих лесных пожаров.

Положительный эффект достигается тем, что на лесные квартала с большим количеством лесных пожаров, происшедших в прошлом, выделяется больше внимания и времени контроля системы «Дозор». Это позволяет повысить эффективность регистрации новых лесных пожаров.

Новизна технического решения заключается в том, что впервые за объект исследования принимают не лесные пожары как таковые, имеющие непроизвольные координаты для наблюдения, а лесные квартала как физические объекты с постоянными параметрами (координаты в виде радиуса и угла направления радиуса до лесного квартала).

\section{Список литературы}

1. Мазуркин П.М., Блинова К.С. Активность Солнца и годичная динамика лесных пожаров на особо охраняемой территории // Успехи современного естествознания. 2013. № 1. C.102-107.

2. Мазуркин П.М., Блинова К.С., Хазиев А.В. Асимметричные вейвлет-сигналы многолетней динамики численности лесных пожаров Республики Марий Эл // Вестник Казанского технол. ун-та. 2013. Т. 16. № 15. С.148-151.

3. Мазуркин П.М. Каткова Т.Е. Моделирование многолетней динамики изменения площади лесных пожаров // Вестник Воронежского института ГПС МЧС России. 2013. №1 (6). С.31-37. 
4. Мазуркин П.М. Каткова Т.Е. Анализ многолетней динамики удельной площади лесных пожаров // Вестник Воронежского института ГПС МЧС России. 2013. №2 (7). C.37-43.

5. Мазуркин П.М., Каткова Т.Е. Вейвлет-анализ многолетней динамики локальной численности лесных пожаров // Современные проблемы науки и образования. - 2013. № 5; URL: http://www.science-education.ru/111-10164 (дата обращения: 26.09.2013).

6. Мазуркин П.М., Скорикова Л.А. Динамика температуры горения древесных опилок при испытании сжиганием // Вестник КНИТУ. 2011. № 7. С.58-61.

7. Мазуркин П.М., Филонов А.С. Математическое моделирование. Идентификация однофакторных статистических закономерностей: учеб. пос. Йошкар-Ола: МарГТУ, 2006. 292 c.

8. Пат. 2406079 Российская Федерация, МПК G 01 N 25 / 00, G 01 N 33 / 46 (2006.01). Способ испытания древесных материалов по температуре сгорания / Мазуркин П.М., Кудрявиева Л.А. (РФ); заявитель и патентообладатель Марийск. гос. тех. ун-т. №2009133872/28; заявл. 09.09.2009; опубл. 10.12.2010.

9. Пат. 2449272 Российская Федерация, МПК G 01 N 33/46, A 01 G 23/00 (2006.01). Споосб испытания древесных материалов на горючесть / Мазуркин П.М. Кудрявцева Л.А.; заявитель и патентообладатель Марийский гос. тех. университет. №2009133878/15; заявл. 09.09.2009; опубл. 27.04.2012; Бюл. №12.

10. Пат. 2416793 Российская Федерация, МПК G 01 N 33 / 46, А 62 C 3 / 02 (2006.01). Способ испытания лесных горючих материалов на воспламеняемость / Мазуркин П.М., Кудрявиева Л.А., Егорова Е.А. (РФ); заявитель и патентообладатель МарГТУ. № 2009133875/12; заявл. 09.09.2009; опубл. 20.04.2011. 